\title{
On the parameterization of biological influences on offshore sand wave dynamics
}

\author{
Bastiaan Wijnand Borsje • \\ Suzanne Jacqueline Marie Hélène Hulscher • \\ Peter Maria Jozef Herman - Mindert Bareld de Vries
}

Received: 28 November 2008 / Accepted: 17 April 2009/Published online: 12 May 2009

(C) The Author(s) 2009. This article is published with open access at Springerlink.com

\begin{abstract}
The bed of the North Sea is covered by sand waves and houses a great number of macrobenthic animals. These bio-engineers are known to have a significant influence on the stability of the bed and thereby on the geomorphology of the seabed. This paper proposes a parameterization of these bio-geomorphological interactions. Given the abundance of three dominant bio-engineers on the Dutch Continental Shelf, the predicted occurrence of
\end{abstract}

Responsible Editor: Roger Proctor

B. W. Borsje $(\triangle)$ • S. J. M. H. Hulscher • M. B. de Vries

Water Engineering and Management, University of Twente,

P.O. Box 217, 7500 AE Enschede, The Netherlands

e-mail: b.w.borsje@utwente.nl

S. J. M. H. Hulscher

e-mail: s.j.m.h.hulscher@utwente.nl

M. B. de Vries

e-mail: mindert.devries@deltares.nl

B. W. Borsje $\cdot$ M. B. de Vries

Deltares, Marine and Coastal Systems,

Rotterdamseweg 185, P.O. Box 177, 2600 MH Delft,

The Netherlands

P. M. J. Herman

Centre for Estuarine and Marine Ecology,

Netherlands Institute of Ecology (NIOO-KNAW),

Korringaweg 7, P.O. Box 140, 4400 AC Yerseke, The Netherlands

e-mail: p.herman@nioo.knaw.nl

P. M. J. Herman

Faculty of Environmental Sciences,

Radboud University Nijmegen,

P.O. Box 9102, 6500 HC Nijmegen, The Netherlands

M. B. de Vries

Faculty of Civil Engineering and Geosciences,

Delft University of Technology,

P.O. Box 5048, 2600 GA Delft, The Netherlands sand waves, in which the parameterization is included, shows significantly better results, compared to the prediction for the default case without biology. Therefore, the inclusion of biological activity could be important to predict the occurrence of sand waves.

Keywords Morphological/morphodynamic modeling . Benthos $\cdot$ Parameterization $\cdot$ Stability analysis .

Biogeomorphology $\cdot$ North Sea

\section{List of symbols}

$\alpha$

Bed load transport proportional

$\alpha_{\mathrm{mr}}$

parameter $\left[\mathrm{m} \mathrm{s}^{-2}\right]$

$\beta_{\mathrm{mr}}$

Dimensionless parameter mega ripple regime [-]

Dimensionless parameter mega ripple regime [-]

$\Delta$

Relative density [-]

$\Delta_{\mathrm{r}}$

Mega ripple height [m]

$\Delta_{\mathrm{r}}^{0}$

$\Delta_{\mathrm{r}}^{\text {bio }}$

$\lambda$

$\lambda_{\mathrm{r}}$

$\theta_{\mathrm{cr}}$

$\rho$

$\rho_{\mathrm{S}}$

$\tau_{\mathrm{b}}$

$\tau_{\mathrm{cr}}$

$\tau_{\mathrm{cr}}^{0}$

Mega ripple height in the absence of

biological activity [m]

Mega ripple height due to biological activity [m]

Bed slope correction term [-]

Mega ripple length [m]

Critical shields parameter [-]

Density of seawater $\left[\mathrm{kg} \mathrm{m}^{-3}\right]$

Density of sediment $\left[\mathrm{kg} \mathrm{m}^{-3}\right]$

Bed shear stress vector $[\mathrm{Pa}]$

Critical bed shear stress $[\mathrm{Pa}]$

Critical bed shear stress in the absence of biological activity $[\mathrm{Pa}]$

$\tau_{\mathrm{cr}}^{\text {bio }} \quad$ Critical bed shear stress due to biological activity [Pa]

Kinematic viscosity of water $\left[\mathrm{m}^{2} \mathrm{~s}^{-1}\right]$ 


$\begin{array}{ll}b & \text { Power of transport [-] } \\ C_{\mathrm{d}} & \text { Drag coefficient [-] } \\ d_{50} & \text { Median grain size [mm] } \\ d_{50}^{0} & \text { Median grain size in the absence of } \\ & \text { biological activity [mm] } \\ d_{50}^{\text {bio }} & \text { Median grain size due to biological } \\ & \text { activity [mm] } \\ D^{*} & \text { Dimensionless grain size [-] } \\ f_{\text {Echinocardium,stab }} & \text { Stabilizing factor for the median grain } \\ & \text { size [-] } \\ f_{\text {Lanice,stab }} & \text { Stabilizing factor for the ripple height [-] } \\ f_{\text {Tellina,destab }} & \text { Destabilizing factor for the critical bed } \\ & \text { shear stress [-] } \\ g & \left.\text { Gravitational acceleration [m s }{ }^{-2}\right] \\ h & \text { Height of the bed form [m] } \\ H & \text { Local water depth [m] } \\ \mathrm{H} & \text { Heaviside function } \\ l_{\text {bio }} & \text { Thickness of the bio-turbated layer [m] } \\ \mathbf{S}_{\mathrm{b}} & \text { Volumetric sediment transport } \\ \mathbf{u} & \left.\text { vector [m }{ }^{2} \mathrm{~s} \text {-1 }\right] \\ z_{0} & \left.\text { Flow velocity vector [m s }{ }^{-1}\right] \\ z_{0, \text { skin }} & \text { Level of zero intercept [m] } \\ & \text { Level of zero intercept due to grain } \\ & \text { size [m] }\end{array}$

\section{Introduction}

The interaction between benthos and sediment dynamics in the intertidal area has been exhaustively documented (e.g., Widdows and Brinsley 2002, and references therein). They show that benthos are able to influence the strength of the bed by several orders of magnitude, and thereby, have a significant influence on the sediment dynamics on a large spatial and temporal scale, either by stabilizing or destabilizing the sediment (Borsje et al. 2008). However, benthos are also present in shallow shelf sea (Heip et al. 1992; Künitzer et al. 1992; Rabaut et al. 2007), for which the North Sea is an example. Although the biomass in the North Sea area is much smaller compared to the benthos biomass per unit area in intertidal area, we still expect strong interactions in the North Sea area (Borsje et al. 2009).

At the bed of the North Sea, sand waves are excessively present; these rhythmic features can grow up to $25 \%$ of the water depth and migrate with a speed up to tens of meters per year (Tobias 1989). The migration of these sand waves can conflict with economic interests like navigation and the exposure of oil pipes or telecommunication cables (Morelissen et al. 2003; Németh et al. 2003).

Sand wave occurrence in the North Sea was first modeled by Hulscher and Van den Brink (2001). Van der Veen et al. (2006) improved the prediction of sand wave occurrence by including both a spatially varying grain size and a threshold for erosion (critical bed shear stress). Recently, different models were proposed (Besio et al. 2006; Németh et al. 2007) by which also the dimensions (wave height and wave length) and migration of sand waves can be predicted. However, all models lack correction for biological activity. In order to predict these biogeomorphological interactions in offshore sand wave occurrence, we first need a tool to correct the hydrodynamics and sediment dynamics for biological activity.

The aims of this paper are (a) to propose a parameterization in which biological activity is expressed in physical parameters and (b) to validate this parameterization with field data from the Dutch North Sea.

The paper is organized as follows. Section 2 describes the selection and the parameterization of three benthic species. The validation of the parameterization is discussed in Section 3, where the occurrence of sand waves for the Dutch part of the North Sea is modeled both for the case without biological activity and the case in which the parameterization is included. The main findings of this paper are discussed in Section 4, and we draw conclusions in Section 5.

\section{Parameterization of biological activity}

Three benthic species are included in the parameterization on the basis of (a) their abundance in the North Sea, (b) their strong modification of the environment they are living in, and (c) their contrasting type of feeding and burrowing, and thereby contrasting influence on the sediment dynamics and hydrodynamics. The three species selected are Lanice conchilega, Tellina fabula, and Echinocardium cordatum. The selection of the benthic species is discussed in more detail by Borsje et al. (2009).

The interaction between the selected benthos and the environment is schematized in Fig. 1. The tube-building worm L. conchilega protrudes several centimeters from the sediment in the water column, and thereby, influences the near-bottom flow. For dense tube assemblages, the nearbottom flow reduces, fine sediment will deposit, and consequently lower ripples are present (Fig. 1b), compared to the default case (Fig. 1a). Due to the digging and feeding activities of the bivalve $T$. fabula up to $10 \mathrm{~cm}$ deep in the sediment, the properties of the surficial sediment are modified and the sediment is more prone to erosion (Fig. 1c). Finally, the sea urchin E. cordatum lives in the top $20 \mathrm{~cm}$ of the bed and mixes sediment in a vertical direction (Fig. 1d), resulting in relatively coarser sediment in the top layer of the bed.

Both the stabilizing and destabilizing effects of benthic organisms are parameterized by means of modification of 
Fig. 1 Schematized interaction between the selected benthos and their environment. For the default case (a), the sediment fractions are normally distributed over the bed, ripples are present at the sediment-water interface, and the flow velocity profile represents the normal case. Lanice conchilega (b) reduces the near-bottom flow, and hence, the ripples are lowered. Tellina fabula (c) destabilizes the sediment and thereby increases the pore volume. Echinocardium cordatum (d) redistributes the sediment, resulting in a coarser surface layer and a finer subsurface layer

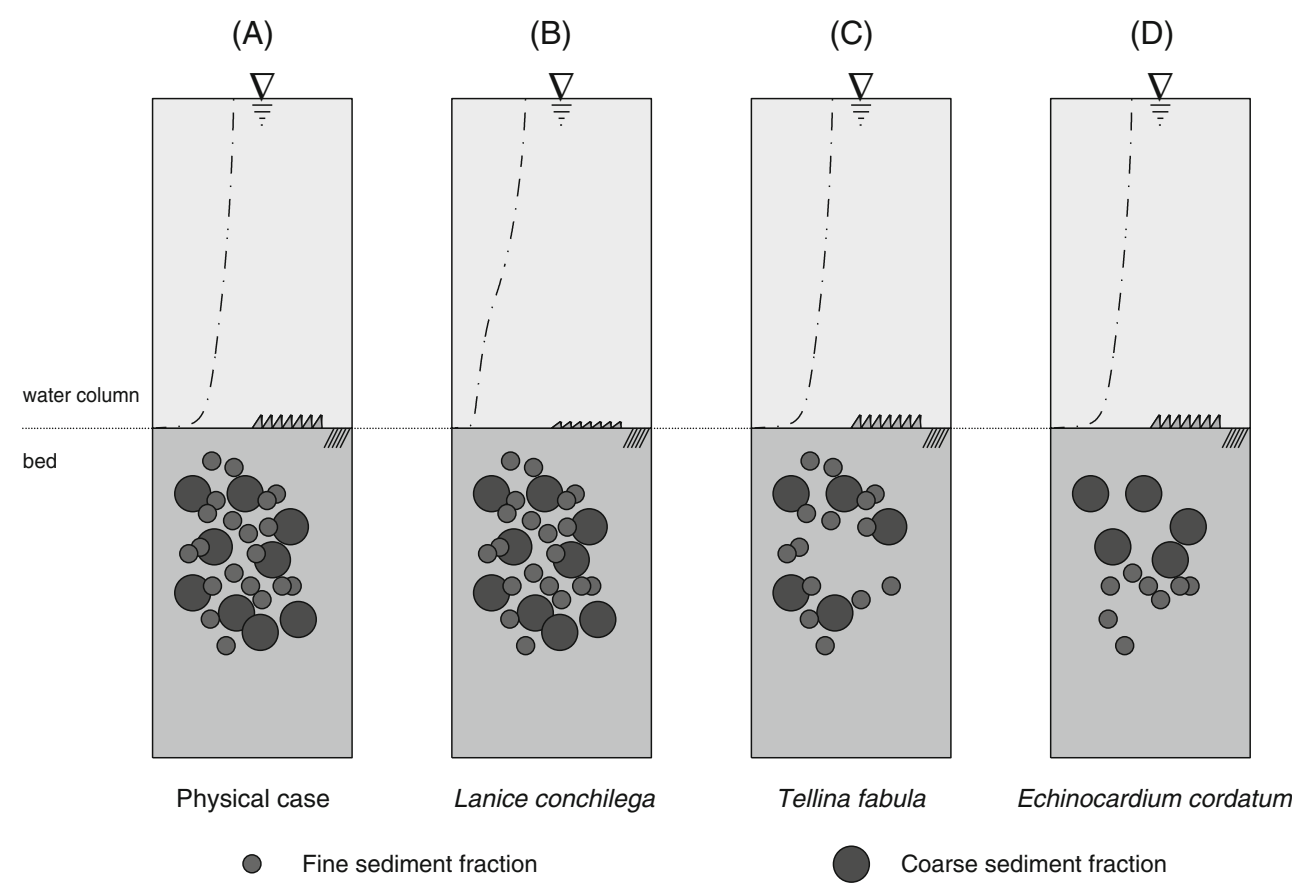

the model parameters, following the suggestion by Knaapen et al. (2003):

$x^{\text {bio }}=x^{0} f_{\text {species, }(\mathrm{de}) \text { stab }}$,

in which $x$ is the model parameter, which is influenced by biological activity. The superscript "bio" represents the value of the parameter $x$ due to biological activity and the superscript " 0 " represents the value of the parameter $x$ without the influence of biological activity. The parameter $f_{\text {species,(de)stab }}$ represents the stabilizing effect and destabilizing effect of the different benthic organisms, respectively. The (de)stabilizing effect is a function of the biomass/ abundance of the benthic organisms, as will be discussed for the individual species in the following sections.

\subsection{Tube-building worm-L. conchilega}

To model the influence of $L$. conchilega on the near-bottom flow, we represent the tube-building worm by thin piles on the bottom of the seabed. In this way, we are able to include the worms in a vegetation model (Uittenbogaard 2003). This vegetation model is able to calculate the turbulent flow over and through vegetation (thin piles) in water of limited depth. The vegetation model explicitly accounts for the influence of cylindrical structures on drag and turbulence by an extra source term of friction force in the momentum equation and an extra source term of total kinetic energy and turbulent energy dissipation in the $k-\varepsilon$ equations, respectively. The vegetation model is included in the
Delft3D-FLOW model, which is a three-dimensional hydrodynamic model (Lesser et al. 2004). The Delft3DFLOW model computes flow characteristics (flow velocity, turbulence) dynamically in time over a three-dimensional spatial grid. For a detailed mathematical description of the vegetation model, see Bouma et al. (2007).

Validation of the model outcome is done for two cases. In both cases, L. conchilega was mimicked by artificial tubes placed in a regular pattern (Fig. 2). Flow velocity profiles in front of the tube field and after the tube field are compared. The first case consists of a flume experiment with an abundance of 350 individuals $\mathrm{m}^{-2}$, a free stream velocity of $0.1 \mathrm{~m} \mathrm{~s}^{-1}$, and a tube height of $10 \mathrm{~cm}$. The modeled flow deceleration of $56 \%$ corresponds well with measured reduction of flow velocity of around $60 \%$ (Friedrichs 1997). The second case consists of a more recent flume experiment (Friedrichs et al. 2000), with a free stream velocity of $0.05 \mathrm{~m} \mathrm{~s}^{-1}$, a variation in the abundance of 490 to 3,836 individuals $\mathrm{m}^{-2}$ and a tube height of $3.5 \mathrm{~cm}$. Due to the fact that the height of the bottom boundary layer $(\sim 3 \mathrm{~cm})$ was comparable to the height of the tubes, Friedrichs et al. (2000) discuss that the results may vary with different experimental settings, but that the results are qualitatively correct. Nevertheless, the reduction in the near-bottom flow velocity modeled with a tube height of $10 \mathrm{~cm}$ and a free stream velocity of $0.05 \mathrm{~m} \mathrm{~s}^{-1}$ shows comparable results with the measured flow deceleration in the flume (Fig. 3). Comparing these flume and model experiments is acceptable, while the population density and not tube height is the main determinant in the deceleration 
Fig. 2 Schematic overview of the model set-up to determine the reduction of the flow velocity by Lanice conchilega. Flow velocity profiles correspond to the indicated densities (individuals per square meter)
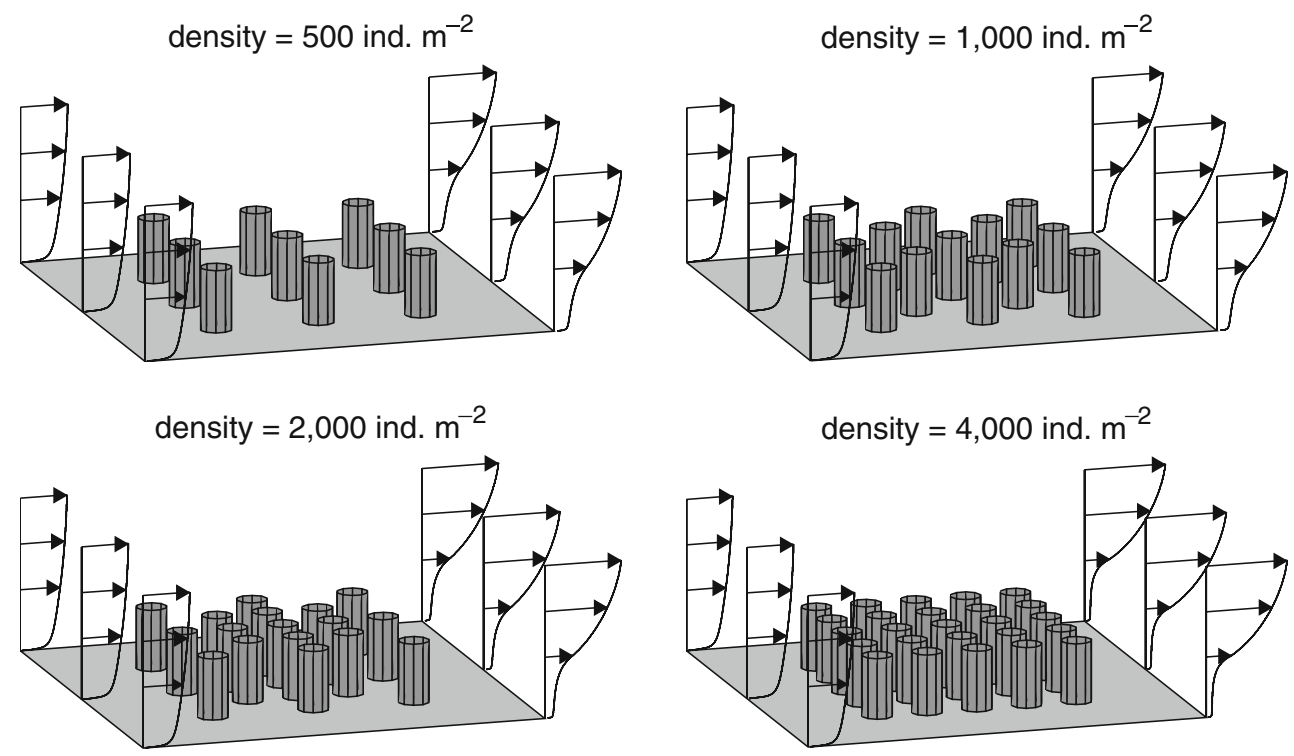

of the flow (Nowell and Church 1979). Population densities used in the flume experiments are comparable to density distribution measured in the field for L. conchilega.

The flow deceleration by $L$. conchilega will reduce the ripple height both directly and indirectly, as observed in the field by Featherstone and Risk (1977): directly, by a decrease in energy near the bed, and indirectly, due to deposition of fine particles in the tube fields and consequently lower ripples. Moreover, another indirect effect is the augmentation of the benthic community with the presence of L. conchilega (Rabaut et al. 2007). These bioengineers burrow and crawl through the top layer of the sediment and in this way break down the ripples. Reduction of the ripple height in the field is site-specific (local sediment sorting, amount of suspended sediment, and abundance of burrowing and crawling species), and therefore difficult to express in general terms. However, following the empirical relations derived by O'Donoghue et al. (2006), the ripple height will reduce to $60 \%$, given a reduction of the near-bottom flow to $30 \%$ of the original nearbottom flow velocity. A reduction of $70 \%$ of the bottom flow is chosen to represent the maximum density of $L$. conchilega found in the North Sea area (Borsje et al. 2009). Assuming a breakdown of the ripples by $10 \%$ due to the burrowing and crawling of the bio-engineers, the maximum reduction of the ripple height is $70 \%\left(f_{\text {Lanice, stab }}=0.3\right)$.

\subsection{Bivalve-T. fabula}

Data on the bio-engineering capacity of the bivalve $T$. fabula are scarce, but the sediment modification by the bivalve Macoma balthica is much better known. Both bivalves have comparable feeding strategies (selective deposit as well suspension feeding). However, M. balthica is mostly found in muddy sediments, while T. fabula prefers fine sand sediments. Therefore, the distribution of $M$. balthica is much more bordered close to the coast, in contrast to T. fabula which can be found in all other parts of the North Sea. Nevertheless, the relation used for M. balthica to parameterize the sediment destabilization is a good alternative to model the bio-sediment interactions for $T$. fabula. The biomass of the bivalve is related to the critical bed shear stress by a destabilizing factor $\left(f_{\text {Tellina,destab }}\right)$. The destabilizing factor is defined by Borsje et al. (2008), based on field experiments by Austen et al. (1999), and quantitatively shown in Fig. 4.

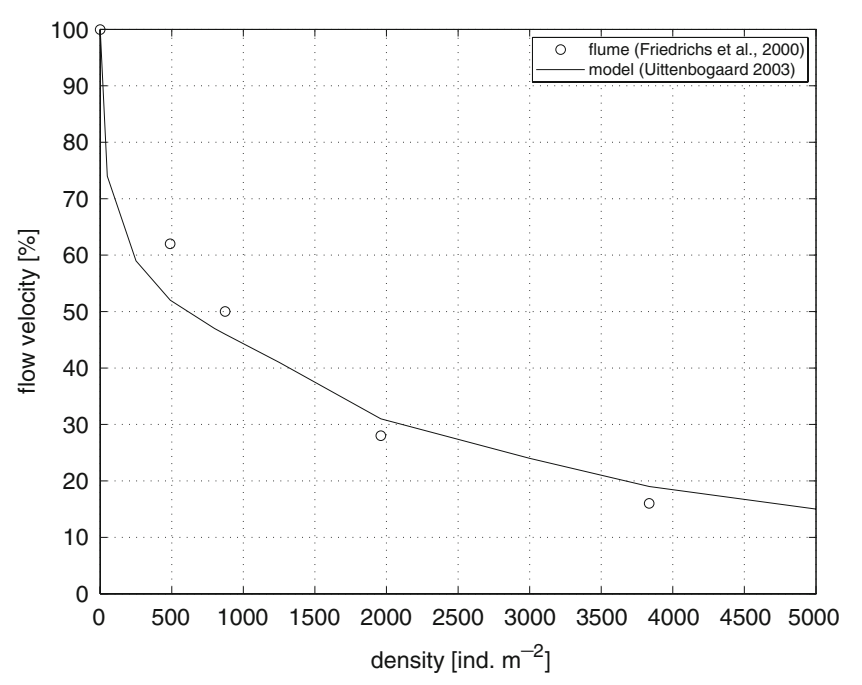

Fig. 3 Comparison between the flow deceleration by Lanice conchilega for different densities, mimicked in a flume experiment by thin piles (Friedrichs et al. 2000) and model results, by adopting the vegetation model by Uittenbogaard (2003). Deceleration expressed as flow velocity in percent of reference velocity at $1.5 \mathrm{~cm}$ above the sediment surface 


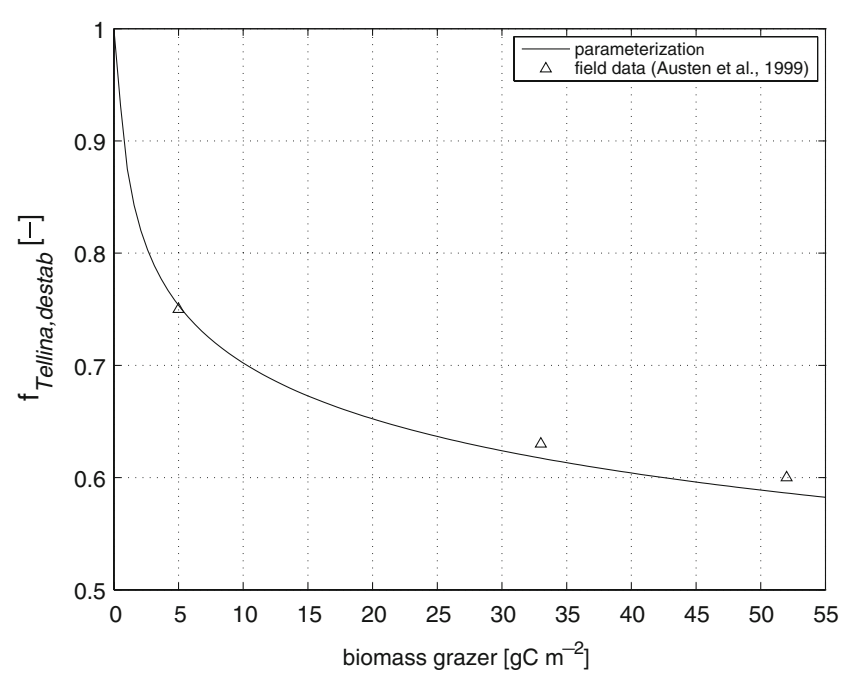

Fig. 4 Destabilization of the bed by Tellina fabula, expressed in a destabilization factor $\left(f_{\text {Tellina,destab }}\right)$ on the critical bed shear stress, adapted from Borsje et al. (2008)

\subsection{Sea urchin-E. cordatum}

E. cordatum causes a change in sediment distribution in the bed, resulting in a relatively coarser layer at the sediment water interface, and relatively finer layer of sediment underneath this layer. E. cordatum is regarded as a nonselective deposit feeder (Lohrer et al. 2005). However, fine particles which have a higher relative surface area and a higher organic content than coarse particles (Burone et al. 2003) have a higher probability of being ingested and brought downward than coarse particles (Cramer et al. 1991). This causes the heterogeneous sediment distribution in the top centimeters of the bed. To parameterize the transport of particles from the sediment surface deeper into the sediment by E. cordatum, we adopt an active layer concept. In this concept, the probability of entrainment of a particle is defined in a step function, for which the probability of entrainment of a particle has a constant value in an active layer near the bed surface, and vanishes below this layer (Hirano 1971). The layer underneath the active layer is called the substrate, which is physically covered by the active layer. As a result, the grain size distribution in both layers can be assigned differently. By adopting an active layer thickness which is equal to the area of influence by $E$. cordatum, the top layer can be modeled as a bio-turbated layer, while the substrate can be modeled as a non bioturbated layer. Based on an experimental study for $E$. cordatum in New Zealand, Lohrer et al. (2005) found that E. cordatum displaces up to $20,000 \mathrm{~cm}^{3} \mathrm{~m}^{-2}$ day ${ }^{-1}$, suggesting that surface sediment is reworked about every 3 days at sites where E. cordatum is abundant.

The heterogeneous vertical sediment distribution is shown in Fig. 5, in which the thickness of the bio- turbated layer $\left(l_{\text {bio }}\right)$ and the biological stabilization factor for the median grain size needs to be imposed. Based on measurements of Arenicola marina (Baumfalk 1979), which is also a non-selective deposit feeder, the stabilization factor could reach values up to $2\left(f_{\text {Echinocardium, stab }}=2\right)$, meaning a median grain size twice as large, compared to the default case. The thickness of the bio-turbated layer could reach values up to $0.2 \mathrm{~m}$ (Holtmann et al. 1996).

\section{Modeling bio-geomorphological interactions for offshore sand waves}

Hulscher (1996) was the first who showed that sand waves can be seen as instabilities of the coupled system (sediment dynamics and hydrodynamics). The interaction of the oscillatory tidal flow with sinusoidal bed perturbations gives rise to a tidally averaged residual flow, in the form of vertical re-circulating cells. If the net displacement of the sediment dragged by this resulting flow pattern is directed toward the crests, the amplitude of the perturbation grows. On the other hand, the perturbation decays if the net motion of the sediment is directed towards the troughs of the bed waviness, i.e., decreasing the amplitude.

The theoretical investigation of sand wave appearance forced by tidal motion has mainly been carried out by means of stability analyses. By applying a linear stability analysis to the coupled system, the wavelength and crest orientation with respect to the principal tidal current is determined. Such an analysis has the following steps. First, the basic state is selected, which represents a flat bed subject

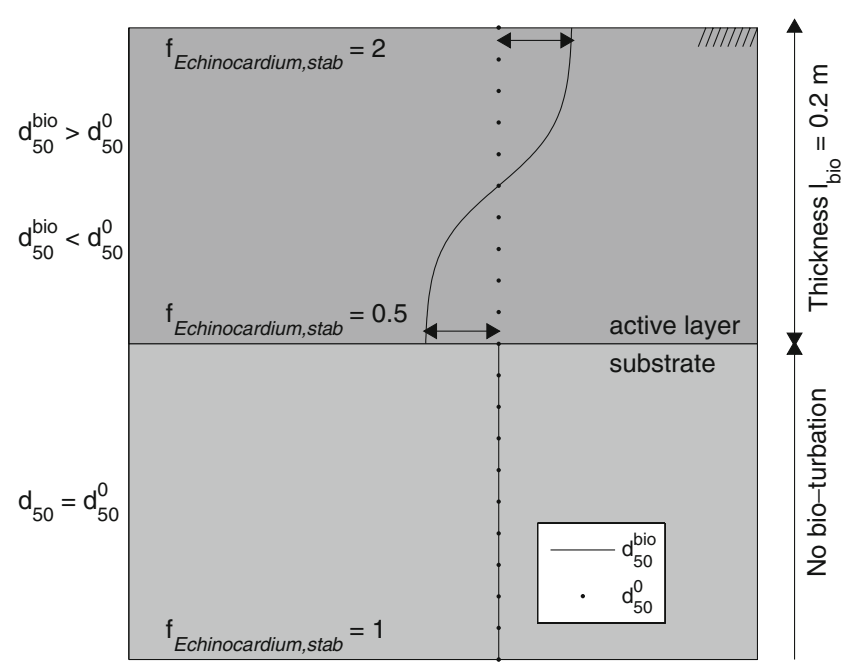

Fig. 5 Schematic overview of the influence of Echinocardium cordatum on the grain size distribution in the bed. Resulting in a larger grain size in the surface layer and a smaller grain size in the subsurface layer $\left(d_{50}^{\text {bio }}\right)$, compared to the physical case $\left(d_{50}^{0}\right)$, expressed in a stabilization factor $\left(f_{\text {Echinocardium, stab }}\right)$. In the substrate, no bioturbation occurs 
to a spatially uniform tidal flow. The second step is the introduction of small amplitude perturbations to the coupled systems and the determination of the growth rate of these perturbations individually. If all growth rates are negative, all bed patterns are damped and we define this as a bed on which no large-scale bed forms occurs. However, if at least one bed pattern has a positive growth rate, the flat bed is unstable and a wavy bed pattern occurs. The wavelength with the fastest growing mode is considered to represent the occurring sand wave. For a detailed explanation on the theory behind the use of linear stability analysis for understanding morphodynamic behavior of coastal systems, see Dodd et al. (2003).

\subsection{Bio-geomorphological model description}

The bio-geomorphological model used in the present paper is based on the work by Hulscher (1996) and later modified by Van der Veen et al. (2006), who developed a large-scale bed form prediction model that uses the parameters water depth, flow velocity, and sediment grain size to give sitespecific predictions for the type of bed form that occurs at a certain location. The bio-geomorphological model is the result of the inclusion of the parameterization of biological processes in the model of Van der Veen et al. (2006).

In the model, only bed load transport is modeled, since Hulscher (1996) assumed that this type of sediment transport is dominant in offshore tidal regimes. The transport equation reads:

$\mathbf{S}_{\mathrm{b}}=\alpha\left|\tau_{\mathrm{b}}\right|^{\mathrm{b}}\left(\frac{\tau_{\mathrm{b}}}{\left|\tau_{\mathrm{b}}\right|}-\lambda \nabla h\right) \mathrm{H}\left(1-\frac{\tau_{\mathrm{cr}}}{\tau_{\mathrm{b}}}\right)$,

where $\mathbf{S}_{\mathrm{b}}$ is the volumetric sediment transport vector, $\alpha$ the bed load proportional parameter, $b$ denotes the non-linearity of transport in relation with the bed shear stress, $\lambda$ is a bed slope correction term, $h$ the height of the bed form, $\tau_{\text {cr }}$ the critical bed shear stress, and $\tau_{\mathrm{b}}$ is the bottom shear stress, and the Heaviside function $\mathrm{H}$ is equal to zero for negative arguments and is equal to 1 for positive arguments.

The bed shear stress according to Soulsby (1997) reads:

$\tau_{\mathrm{b}}=\rho C_{\mathrm{d}} \mathbf{u}^{2}$,

where $\rho$ is the density of seawater, $\mathbf{u}=(u, v)$ is the velocity vector, and $C_{\mathrm{d}}$ is the drag coefficient, defined by:

$C_{\mathrm{d}}=0.0415\left(\frac{z_{0, \text { skin }}}{H}\right)^{\frac{2}{7}}$.

Here, $H$ is the local water depth and $z_{0, \text { skin }}$ is the level of zero intercept (the level above the seabed, where the flow velocity is zero) due to grain size only:

$z_{0, \text { skin }}=\frac{d_{50}}{12}$,

in which $d_{50}$ is the median grain size.
In Eq. 2, the critical bottom shear stress is imposed by:

$\tau_{\mathrm{cr}}=\theta_{\mathrm{cr}} g\left(\rho_{\mathrm{s}}-\rho\right) d_{50}$,

where $g$ is the gravitational acceleration, $\rho_{\mathrm{s}}$ is the density of the sediment, and $\theta_{\text {cr }}$ is the dimensional critical Shields parameter:

$\theta_{\mathrm{cr}}=\frac{0.30}{1+1.2 D^{*}}+0.055\left(1-e^{-0.020 D^{*}}\right)$,

where, $D^{*}$ is the dimensionless sediment parameter, prescribed by:

$D^{*}=d_{50}\left(\frac{\Delta g}{v^{2}}\right)^{\frac{1}{3}}$,

where $\Delta$ is the relative density and $v$ is the kinematic viscosity of water.

Water motion driven by the tide is described with the three-dimensional shallow water equations. The flow model and the sediment transport model are coupled by:

$\frac{\partial h}{\partial t}+\nabla \times \mathbf{S}_{\mathrm{b}}=0$.

Equation 9 simply states that convergence (or divergence) of the sediment flux must be accompanied by a rise (or fall) of the bed profile.

The model can be solved, once the resistance parameter and the Stokes number are prescribed. Van der Veen et al. (2006) give expressions for both parameters, by fitting the partial slip model used in Hulscher (1996) to a more realistic turbulence model including a no-slip condition at the bed and a parabolic eddy viscosity (Hulscher and Roelvink 1997). Among other parameters, in both expressions, the parameter $z_{0}$ appears, which denotes the level above the seabed, where the flow velocity is zero, and reads (Soulsby 1983):

$z_{0}=2 \Delta_{\mathrm{r}}\left(\frac{\Delta_{\mathrm{r}}}{\lambda_{\mathrm{r}}}\right)^{1.4}$,

in which (Van Rijn 1993):

$\Delta_{\mathrm{r}}=\alpha_{\mathrm{mr}} H \quad \lambda_{\mathrm{r}}=\beta_{\mathrm{mr}} H$,

where $\alpha_{\mathrm{mr}}=0.03$ and $\beta_{\mathrm{mr}}=0.5$ denote dimensionless coefficient for the mega ripple regime in the North Sea (Tobias 1989) and $\Delta_{\mathrm{r}}$ and $\lambda_{\mathrm{r}}$ are the mega ripple height and length, respectively.

Based on the values of the resistance parameter and the Stokes number, Hulscher (1996) constructed a diagram in which four separate regions are discerned (flat bed, sandbanks, tide parallel ridges, and sand waves). Following this diagram, we constructed a new diagram in which the appearance of sand waves is expressed in physical parameters (water depth, flow velocity, and grain size; 


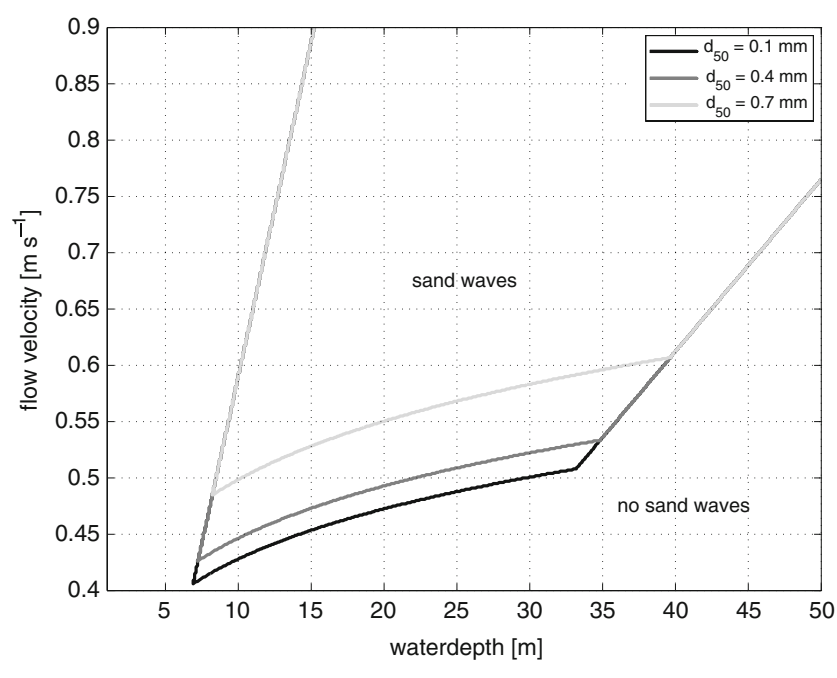

Fig. 6 Diagram to predict the occurrence of sand waves for different water depth, flow velocity, and grain size, modified after Hulscher (1996)

Fig. 6). As a result, we can easily determine whether the model predicts the occurrence of sand waves at a certain location. The diagram is constructed for different grain sizes. Since smaller grain sizes have a smaller critical bed shear stress, the occurrence of sand waves for smaller grain sizes starts at lower energy levels (smaller water depth and smaller flow velocity).
The inclusion of the parameterization is done by adapting Eq. 11 for L. conchilega, Eq. 6 for T. fabula, and Eqs. 5, 6, and 8 for E. cordatum, according to the relations presented in Section 2, which leads to the following expressions:

$\Delta_{\mathrm{r}}^{\mathrm{bio}}=\Delta_{r}^{0} f_{\text {Lanice, } \mathrm{stab}}$

$\tau_{\mathrm{cr}}^{\text {bio }}=\tau_{\mathrm{cr}}^{0} f_{\text {Tellina, destab }}$

$d_{50}^{\text {bio }}=d_{50}^{0} f_{\text {Echinocardium, stab }}$

where $f_{\text {Lanice,stab }}, f_{\text {Tellina,destab, and }} f_{\text {Echinocardium,stab }}$ are the (de)stabilizing biological factor for the ripple height, critical bed shear stress, and grain size, respectively. Again, the superscript " 0 " for the ripple height, critical bed shear stress, and grain size represents the values without the influence of biological activity (default).

\subsection{Study area}

The Dutch part of the North Sea shows a wide range of large-scale bed patterns (Fig. 7). Shoreface-connected ridges are the largest bed forms in the study area. These ridges are with an oblique angle connected to the lower
Fig. 7 a, b Overview of the bathymetry of the Dutch part of the North Sea. Water depths are up to $70 \mathrm{~m}$
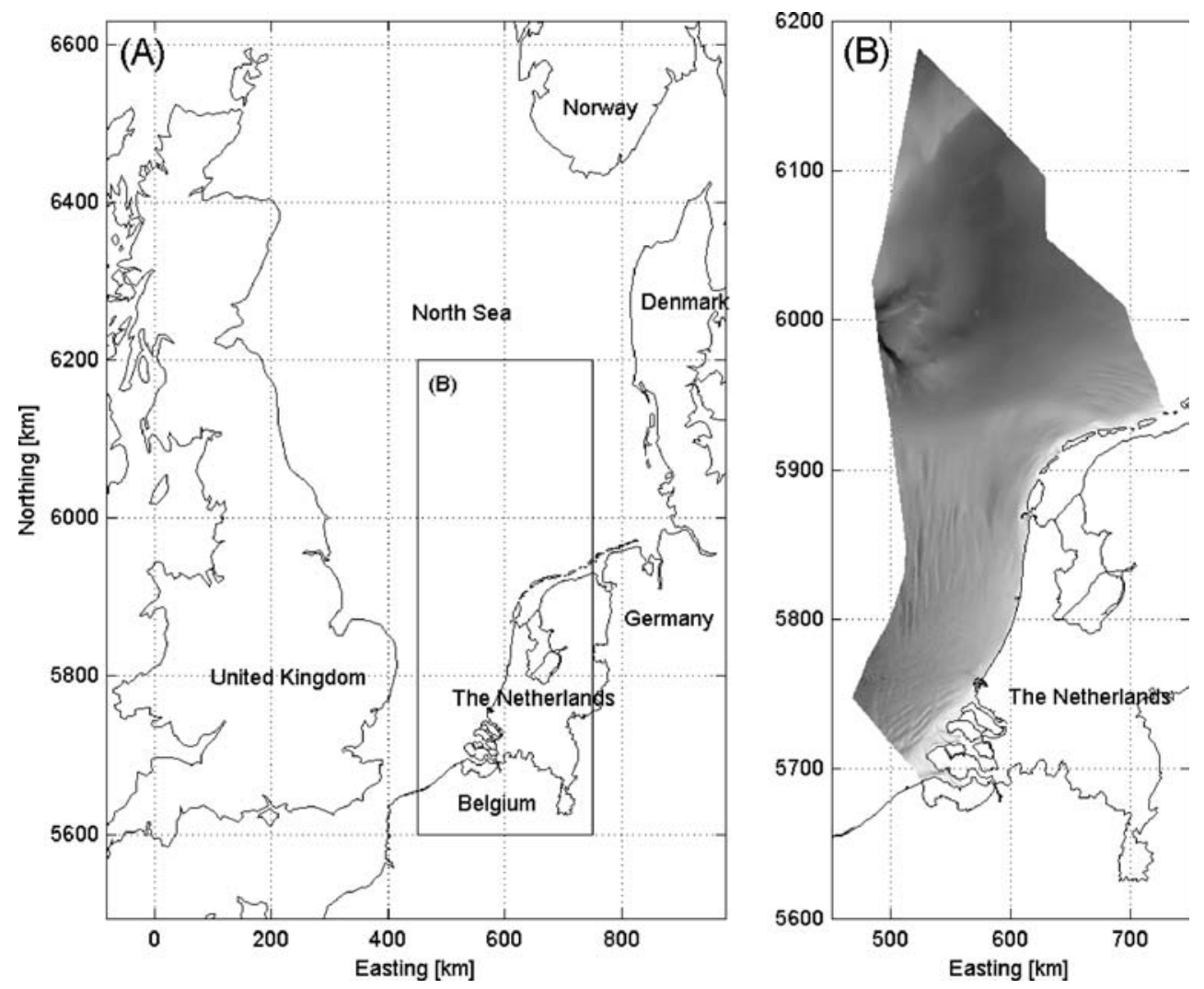
Fig. 8 Contours of high densities of Lanice conchilega (a), Tellina fabula (b), and Echinocardium cordatum (c) on the bed of the Dutch part of the North Sea. Data adapted from Holtmann et al. (1996)

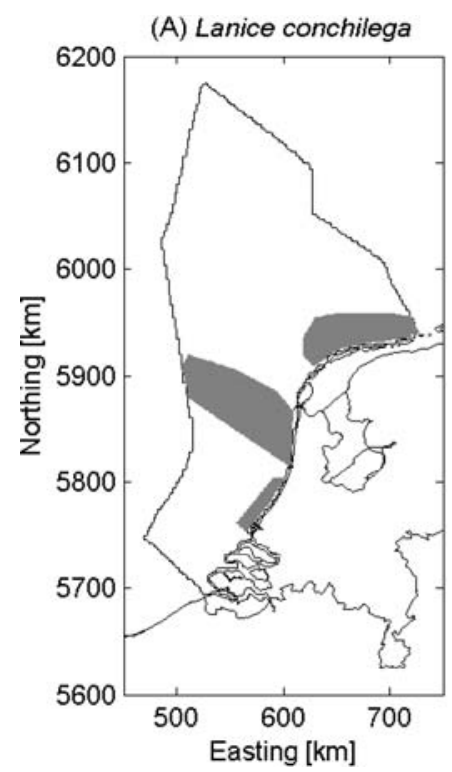

(C) Echinocardium cordatum

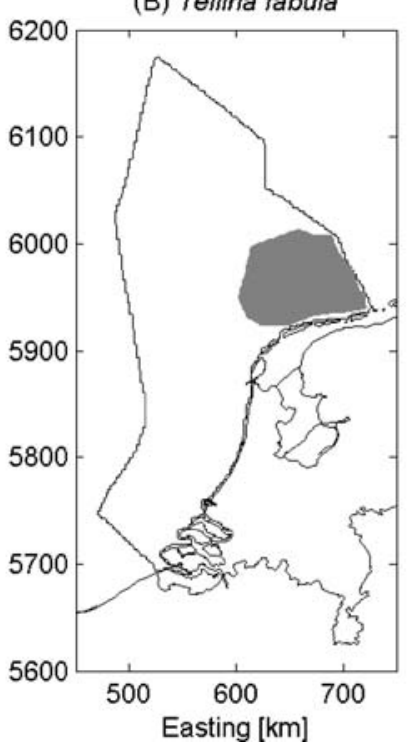

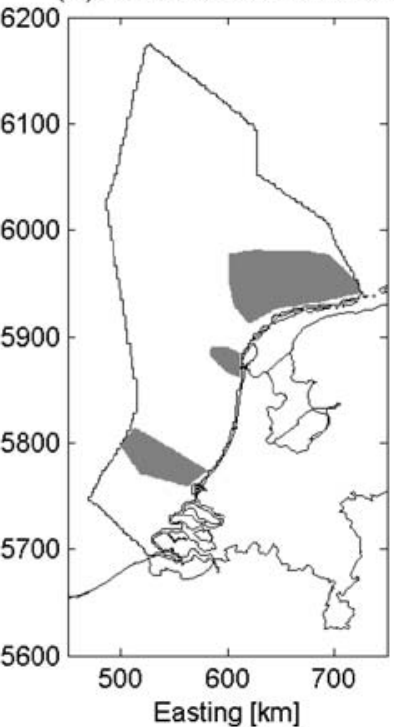

shoreface. Wavelength is in the order of kilometers, and the amplitude of these bed forms is smaller than $3 \mathrm{~m}$ (Van de Meene and Van Rijn 2000). The dimensions of tidal sandbanks are comparable to the dimensions of shorefaceconnected ridges, although tidal sandbanks widely occur in the offshore part of the North Sea and are not only bounded close to the coast (Dyer and Huntley 1999). The spatial scale of sand waves is smaller than that of shorefaceconnected ridges and sand banks. The typical wavelength of sand waves is between 100 and $800 \mathrm{~m}$, and their amplitude is of the order of $5 \mathrm{~m}$ (Tobias 1989). Sand waves have the shortest response time of all bed forms described above. Katoh et al. (1998) showed that sand waves regenerate in several years time. Therefore, we focus on sand waves in
Fig. 9 Adaptation of the prediction diagram (black line) for Lanice conchilega (a), Tellina fabula (b), and Echinocardium cordatum (c), following Eqs. 12, 13, and 14. Median grain size in the absence of biological activity is $0.4 \mathrm{~mm}$
(A) Lanice conchilega

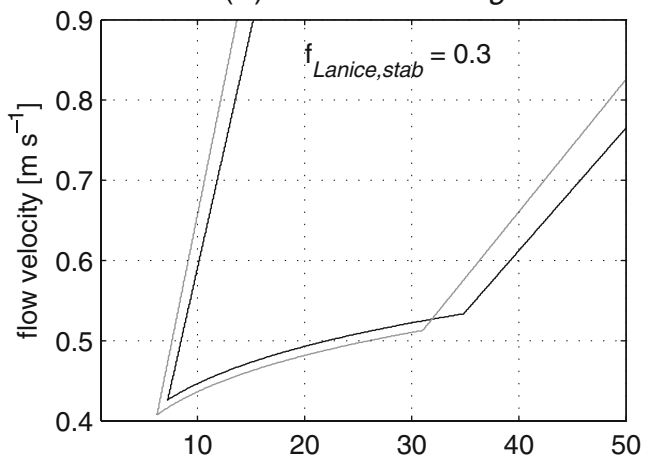

(C) Echinocardium cordatum

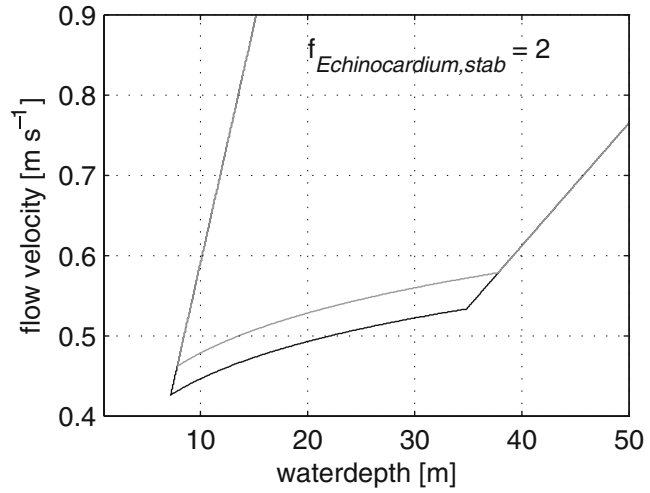

(B) Tellina fabula

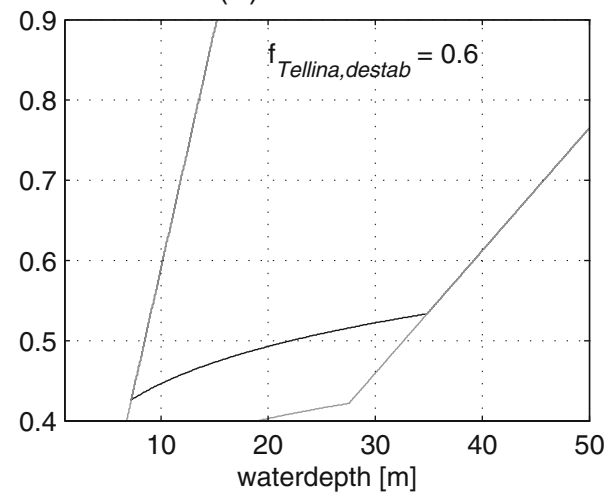

Physical case

Biological case

$$
d_{50}^{0}=0.4 \mathrm{~mm}
$$


this study, while the biological time scale is also assumed to comprise several years (e.g., Barrio Froján et al. 2008).

The spatial distribution of the three bio-engineers is extremely scattered (Holtmann et al. 1996). Therefore, in this study, we will focus on the contours of high densities of the three species (Fig. 8). The spatial pattern of the species distributions in the North Sea matches with that of sand wave fields (Dyer and Huntley 1999), giving us another argument to focus only on the interaction between benthos and sand waves.

\subsection{Results}

By including the maximum adaptation of the process parameters by biological activity in the model, the area in which sand waves occur is influenced for the three different bio-engineers (Fig. 9). Since E. cordatum increases the grain size at the sediment-water interface, the area for which sand waves are predicted decreases, due to the increase of the critical bed shear stress (Eq. 6), as already shown in Fig. 6 for different grain sizes. For the same reason, the area of the occurrence of sand waves for T. fabula is increased, due to a decrease in critical bed shear stress.

L. conchilega is able to decrease the ripple height, and consequently, the level of zero intercept (Eq. 10). Hulscher and Van den Brink (2001) discussed that a decrease in the level of zero intercept will result in a decrease in the area with no model prediction. This results in the occurrence of sand waves at smaller water depths and smaller flow velocities. However, by decreasing the level of zero intercept, also the occurrence of sandbanks is triggered for moderate water depths and flow velocities, resulting in a reduction of the area of occurrence of sand waves.

To validate the proposed parameterization, we compare field data of the occurrence of sand waves adapted from Hulscher and Van den Brink (2001) with model predictions. Data on grain size, water depth, and flow velocity are taken from Borsje et al. (2009). First, we compare the model results for the case in which no biological activity is included in the model (Fig. 10). The observed sand waves are reasonably predicted by the model (Fig. 10a). However, the model results also show a large over-prediction for places where sand waves are predicted and not observed (Fig. 10b).

By including the areas where the three bio-engineers are abundant in the model (Fig. 8), the prediction of the occurrence of sand waves is changed (Fig. 11; compare a and $b)$. The case in which both sand waves are predicted by the model and observed in the field is not much influenced by the included biological activity. However, the quite large over-prediction (column predicted and not observed; Fig. 12) in the model of Van der Veen et al. (2006) is partly restricted by $L$. conchilega and E. cordatum. Both stabilizing species are able to preserve a flat bed for almost $4,000 \mathrm{~km}^{2}$ in the Dutch part of the North, while the physical parameters suggest sand waves. T. fabula destabilize the sediment, and therefore initiates the transport of sediment at lower energy levels, compared to the physical case. As a result, T. fabula is able to decrease the column in which sand waves are not predicted by the model, but observed in the field (Fig. 12; column not predicted and observed). However, this column is quite small in the default model, and therefore, the destabilizer T. fabula is less effective compared to the stabilizers $L$. conchilega and E. cordatum. Therefore, at places where all three bioengineers are abundant (North of the Netherlands), the stabilizers ( $L$. conchilega and E. cordatum) trigger a flat bed, despite the destabilizing effect of $T$. fabula.

Based on these model simulations, we conclude that bioengineers can influence the occurrence of sand waves significantly.

\section{Discussion}

This paper proposes a parameterization on the interaction between benthos on the one hand and sediment dynamics and hydrodynamics on the other hand. Validation of the parameterization is executed with field data on the occurrence
Fig. 10 Comparison between model prediction (line) and field data (black points are sand wave locations (a); gray points are locations without sand waves(b)) of the occurrence of sand waves without the inclusion of biological activity (data adapted from Hulscher and van den Brink 2001)
(A) model $\leftrightarrow$ sand waves

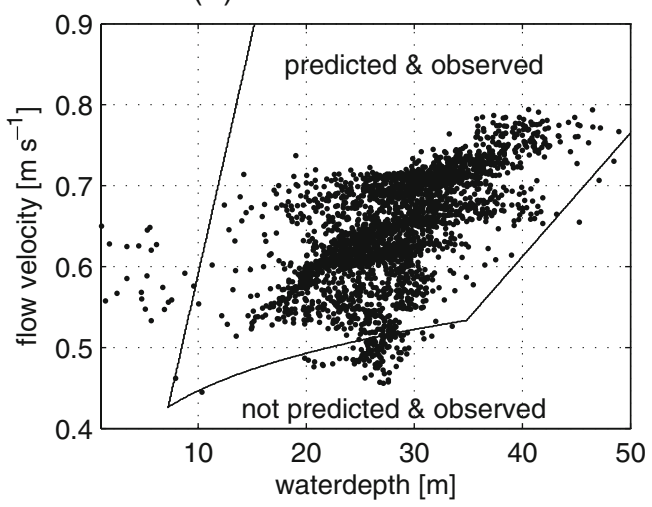

(B) model $\leftrightarrow$ no sand waves

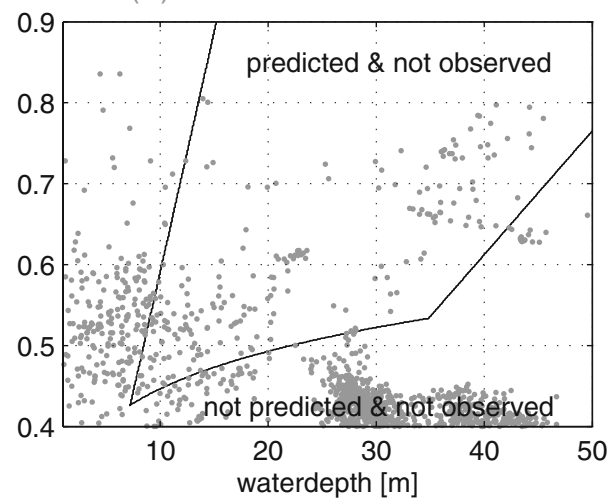


Fig. 11 Spatial prediction of the occurrence of sand waves, both for the morphological case (a) and the bio-geomorphological case (b). Sand waves are absent above $5,950 \mathrm{~km}$ north, and therefore not shown in this figure
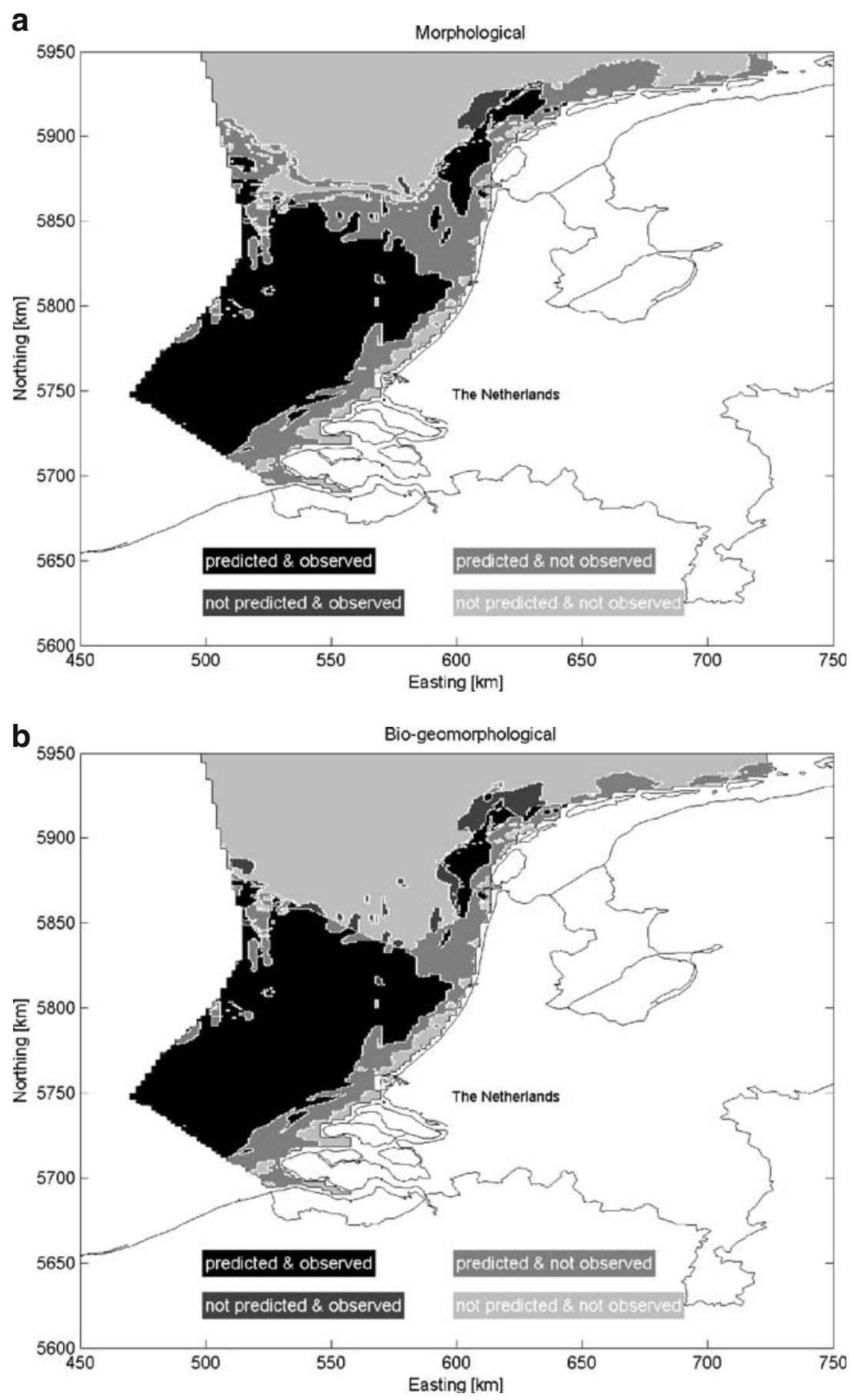

Fig. 12 Results for the morphological case and biogeomorphological case, evaluated against observed sand wave occurrence in the Dutch part of the North Sea

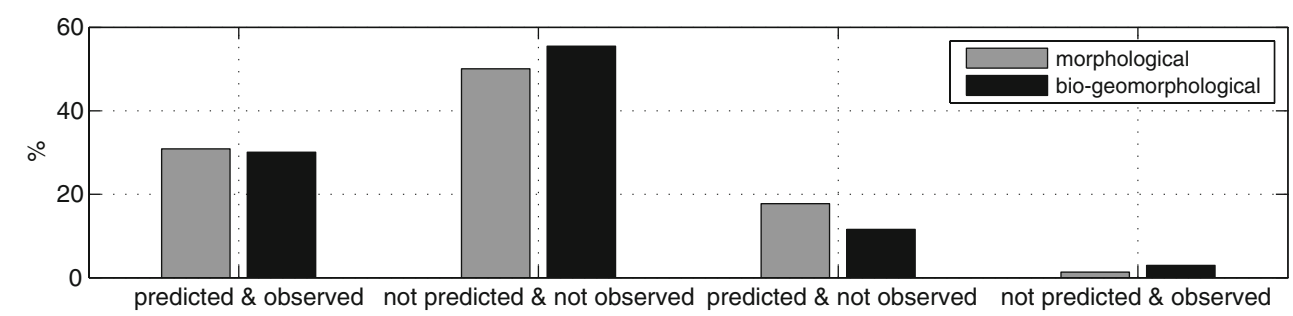


of sand waves from the Dutch part of the North Sea. The aim of this paper is not to predict the occurrence of sand waves exactly. Therefore, we first need more site-specific data of the biomass of bio-engineers at a certain location. In this paper, we only included the biological activity of the parameterized benthos at locations where the bio-engineers are abundant. Only the dominant influences of the three bio-engineers on the sediment dynamics and hydrodynamics found in literature are included in the parameterization of the biological activity. Among the modification of the ripple height, critical bed shear stress and grain size distribution by L. conchilega, T. fabula, and E. cordatum, respectively, as well as other transport parameters might be influenced. New insights can easily be included in the current parameterization, following the suggestion given in Eq. 1.

The prediction of sand waves near the coast is still overpredicted (Fig. 11b). Among local biological activity, also the stabilizing effect of suspended sediment (Besio et al. 2006) may contribute to the absence of sand waves at these nearshore locations. Moreover, wind waves are not included in the model. Waves are considered to act as a stirring mechanism for sediment, such that the suspended sediment concentrations increase, especially near the coast, where the water depth is limited and in this way may influence the dimensions of sand waves (Van Dijk and Kleinhans 2005).

The model used in this paper has recently been extended by different authors (Besio et al. 2006; Németh et al. 2007). Subsequently, it is now also possible to model the dimensions (wave height and wave length) and migration of sand waves. However, in the present paper, we focus on the occurrence of sand waves mainly. The model of Van der Veen (2006) is sufficient for that purpose. Future developments will focus on the impact of benthos on the dimensions and migration speed of sand waves by including the proposed parameterization in the recently developed models. A further important challenge for the future will be to include the effects of temporal variation in benthic biomass on sediment dynamics and hydrodynamics.

A fully coupled biological-physical approach would also necessitate the parameterization of the effect of change in sediment dynamics and hydrodynamics on biological activity. In this way, we are able to couple the biological and morphological system. By combining the habitat suitability studies of Degraer et al. (2008) and Baptist et al. (2006) with the parameterization proposed in this study, a first insight can be given in the feedback from the change in sedimentary processes to the change in biological activity.

\section{Conclusion}

This paper proposes a parameterization on the interaction between three subtidal benthic species on the one hand and sediment dynamics and hydrodynamics on the other hand. By including this parameterization in an idealized sand wave model, the occurrence of sand waves is significantly better predicted, compared to the default case. In summary, biota are able to preserve a stable flat bed, while the physical conditions suggest bed patterns. Likewise, the opposite effect is induced by destabilizing benthos.

In reality, many more benthic species are present in the North Sea, with a much more variable and finer-grained spatial distribution than modeled in this paper. Moreover, the temporal variation at seasonal and year-to-year scales needs to be accounted for when extending the models to predict seabed dynamics. However, the inclusion of the three most relevant bio-engineers in the North Sea already shows the necessity to account for bio-geomorphological interactions in predicting sand wave occurrence in shallow shelf seas.

Acknowledgments The presented research is part of the Ph.D. research of the first author, which is supported by the Dutch Technology Foundation STW, Applied Science Division of NWO, and the Technology Program of the Dutch Ministry of Economic Affairs. We acknowledge Dr. Ir. Henriet van der Veen for providing the idealized sand wave model. The constructive comments of two anonymous reviewers are highly appreciated. This is NIOO publication number 4524 .

Open Access This article is distributed under the terms of the Creative Commons Attribution Noncommercial License which permits any noncommercial use, distribution, and reproduction in any medium, provided the original author(s) and source are credited.

\section{References}

Austen I, Andersen TJ, Edelvang K (1999) The influence of benthic diatoms and invertebrates on the erodibility of an intertidal mudflat, the Danish Wadden Sea. Estuar Coast Shelf Sci 49:99 111. doi:10.1006/ecss. 1998.0491

Baptist MJ, van Dalfsen J, Weber A, Passchier S, van Heteren S (2006) The distribution of macrozoobenthos in the Southern North Sea in relation to meso-scale bedforms. Estuar Coast Shelf Sci 68:538-546. doi:10.1016/j.ecss.2006.02.023

Barrio Froján CRS, Boyd SE, Cooper KM, Eggleteon JD, Ware Z (2008) Long-term benthic responses to sustained disturbance by aggregate extraction in an area off the east coast of the United Kingdom. Estuar Coast Shelf Sci 79:204-212. doi:10.1016/j. ecss.2008.03.023

Baumfalk YA (1979) Heterogeneous grain size distribution in tidal flat sediment caused by bioturbation activity of Arenicola marine (polychaeta). Neth J Sea Res 13:428-440. doi:10.1016/00777579(79)90016-4

Besio G, Blondeaux P, Vittori G (2006) On the formation of sand waves and sand banks. J Fluid Mech 557:1-27. doi:10.1017/ S0022112006009256

Borsje BW, De Vries MB, Hulscher SJMH, De Boer GJ (2008) Modeling large-scale cohesive sediment transport affected by small-scale biological activity. Estuar Coast Shelf Sci 78:468480. doi:10.1016/j.ecss.2008.01.009

Borsje BW, de Vries MB, Bouma TJ, Besio G, Hulscher SJMH, Herman PMJ (2009) Modeling bio-geomorphological influences for offshore sandwaves. Cont Shelf Res 29(9):1289-1301, 15 May 2009, ISSN 0278-4343, doi:10.1016/j.csr.2009.02.008 
Bouma TJ, van Duren LA, Temmerman S, Claverie T, Blanco-Garcia A, Ysebaert T, Herman PMJ (2007) Spatial flow and sedimentation patterns within patch of epibenthic structures: combining field, flume and modeling experiments. Cont Shelf Res 27:10201045. doi:10.1016/j.csr.2005.12.019

Burone L, Muniz P, Pires-Vanin AMS, Rodrigues M (2003) Spatial distribution of organic matter in the surface sediments of Ubatuba Bay (Southeastern-Brazil). An Acad Bras Cienc 75:77-90

Cramer A, Duineveld GCA, Jenness MI (1991) Observations on spatial distribution, metabolism and feeding strategy of Echinocardium cordatum (Pennant) (Echinodermata) and the implications for its energy budget. In: Cramer A (ed) Benthic metabolic activity at frontal systems in the North Sea. Ph.D. Thesis, University of Amsterdam, Amsterdam, pp 63-74

Degraer S, Verfaillie E, Willems W, Adriaens E, Vincx M, Van Lancker V (2008) Habiat suitability modelling as a mapping tool for macrobenthic communities: an example from the Belgian part of the North Sea. Cont Shelf Res 28:369-379. doi:10.1016/j.csr.2007.09.001

Dodd N, Blondeaux P, Calvete D, De Swart H, Falques A, Hulscher SJMH, Rozynski G, Vittori G (2003) The use of stability methods for understanding the morphodynamical behaviour of coastal systems. J Coast Res 19:849-865

Dyer KR, Huntley DA (1999) The origin, classification and modeling of sandbanks and ridges. Cont Shelf Res 19:1285-1330. doi:10.1016/S0278-4343(99)00028-X

Featherstone RP, Risk MJ (1977) Effects of tube-building polychaetes on intertidal sediments of the Minas Basin, Bay of Fundy. J Sediment Petrol 47:446-450

Friedrichs M (1997) Report about the characteristics of the NIOOCEMO flume system-pilot study. NIOO-CEMO, NI00 rapporten 1997-6, Yerseke

Friedrichs M, Graf G, Spring B (2000) Skimming flow induced over a simulated polychaete tube lawn at low population densities. Mar Ecol Prog Ser 192:219-228. doi:10.3354/meps192219

Heip C, Basford D, Craeymeersch JA, Dewarumez J-M, Dörjes J, De Wilde P, Duineveld G, Eleftheriou A, Herman PMJ, Niermann U, Kingston P, Künitzer A, Rachor E, Rumohr H, Soetaert K, Soltwedel T (1992) Trends in biomass, density and diversity of North Sea macrofauna. J Mar Sci 49:13-22

Hirano M (1971) River bed degradation with armouring. Proc Jap Soc Civil Eng 195:55-65

Holtmann SE, Groenewold A, Schrader KHM, Asjes J, Craeymeersch JA, Duineveld GCA, van Bostelen AJ, van der Meer J (1996) Atlas of the zoobenthos of the Dutch Continental Shelf. Ministry of Transport, Public Works and Water Management, North Sea Directorate, Rijswijk, p 244

Hulscher SJMH (1996) Tidal-induced large-scale regular bed form patterns in a three-dimensional shallow water model. J Geophys Res C9(101):20727-20744

Hulscher SJMH, Roelvink JA (1997) Comparison between predicted and observed large-scale sea bed features in the southern North Sea. Technical Report, University of Twente

Hulscher SJMH, Van den Brink GM (2001) Comparison between predicted and observed sand waves and sand banks in the North Sea. J Geophys Res C5(106):9327-9338

Katoh K, Kume H, Kuroki K, Hasegawa J (1998) The development of snad waves and the maintenance of navigation channels in the Bisanteto Sea. In Proceedings of International Conference on Coastal Engineering, pp 3490-3502

Knaapen MAF, Holzhauer H, Hulscher SJMH, Baptist MJ, De Vries MB, Van Ledden M (2003) On the modelling of biological effects on morphology in estuaries and seas. In: Sánchez-Arcilla A, Bateman A (eds) Proceedings of the Third IAHR Symposium on River, Coastal and Estuarine Morphodynamics Conference. IAHR, Barcelona, Spain, pp 773-783

Künitzer A, Duineveld GCA, Basford D, Dewarumez J-M, Dörjes J, Eleftheriou A, Heip C, Herman PMJ, Kingston P, Niermann U, Rumohr H, De Wilde PAWJ (1992) The benthic infauna of the North Sea: species distribution and assemblages. J Mar Sci 49:127-143

Lesser G, Roelvink J, van Kester J, Stelling G (2004) Development and validation of a three-dimensional morphological model. Coast Eng 51:883-915. doi:10.1016/j.coastaleng.2004.07.014

Lohrer AM, Thrush SF, Hunt L, Hancock N, Lundquist C (2005) Rapid reworking of subtidal sediments by burrowing spatangoid urchins. J Exp Mar Biol Ecol 321:155-169. doi:10.1016/j. jembe.2005.02.002

Morelissen R, Hulscher SJMH, Knaapen MAF, Németh AA, Bijker R (2003) Mathematical modeling of sand wave migration and the interaction with pipelines. Coast Eng 48:197-209. doi:10.1016/ S0378-3839(03)00028-0

Németh AA, Hulscher SJMH, De Vriend HJ (2003) Offshore sand wave dynamics, engineering problems and future solutions. Pipeline Gas J 230:67-69

Németh AA, Hulscher SJMH, Van Damme RMJ (2007) Modelling offshore sand wave evolution. Cont Shelf Res 27:713-728. doi:10.1016/j.csr.2006.11.010

Nowell ARM, Church M (1979) Turbulent flow in a depth-limited boundary layer. J Geophys Res 84:4816-4824. doi:10.1029/ JC084iC08p04816

O’Donoghue T, Doucette JS, van der Werf JJ, Ribberink JS (2006) The dimensions of sand ripples in full-scale oscillatory flows. Coast Eng 53:997-1012. doi:10.1016/j.coastaleng.2006.06.008

Rabaut M, Guilini K, Van Hoey G, Vincx M, Degraer S (2007) A bioengineered soft-bottom environment: the impact of Lanice conchilega on the benthic species-specific densities and community structure. Estuar Coast Shelf Sci 75:525-536. doi:10.1016/j. ecss.2007.05.041

Soulsby RL (1983) The bottom boundary layer of shelf seas. In: Johns B (ed) Physical oceanography of coastal and shelf seas. Elsevier, Amsterdam, pp 189-266

Soulsby RL (1997) Dynamics of marine sands: a manual for practical applications. Thomas Telford, London

Tobias CJ (1989) Morphology of sand waves in relation to current, sediment and wave data along the Eurogeul, North Sea; Report GEOPRO 1989.01; Department of Physical Geography, University of Utrecht, The Netherlands

Uittenbogaard R (2003) Modelling turbulence in vegetated aquatic flows. In International workshop on RIParian FORest vegetated channels: hydraulic, morphological and ecological aspects, 2022 February 2003, Trento, Italy, 2003

Van de Meene JWH, van Rijn LC (2000) The shoreface-connected ridges along the central Dutch coast - part 1: field observations. Cont Shelf Res 20:2295-2323. doi:10.1016/S0278-4343(00)00048-0

Van der Veen HH, Hulscher SJMH, Knaapen MAF (2006) Grain size dependency in the occurrence of sand waves. Ocean Dyn 56:228-234. doi:10.1007/s10236-005-0049-7

Van Dijk TAGP, Kleinhans MG (2005) Processes controlling the dynamics of compound sand waves in the North Sea, Netherlands. J Geophys Res 110:F04S10

Van Rijn LC (1993) Principles of sediment transport in rivers, estuaries and coastal seas. Aqua, Amsterdam

Widdows J, Brinsley MD (2002) Impact of biotic and abiotic processes on sediment dynamics and the consequences to the structure and functioning of the intertidal zone. J Sea Res 48:143-156. doi:10.1016/S1385-1101(02)00148-X 